\title{
Maltose excretion by the symbiotic Chlorella of the heliozoan Acanthocystis turfacea
}

\author{
Bettina Matzke, Elisabeth Schwarzmeier, and Eckhard Loos* \\ Lehrstuhl für Zellbiologie und Pflanzenphysiologie, Universität Regensburg. Universitätsstrasse 31, D-84(0) Regensburg. \\ Federal Republic of Germany
}

\begin{abstract}
Chlorella sp. strain 3.83, a symbiotic Chlorella isolated from the heliozoan Acanthocystis turfacea, excreted between $8 \%$ and $16 \%$ of assimilated ${ }^{14} \mathrm{CO}_{2}$ as maltose in the light $(15000 \mathrm{~lx})$, with a $\mathrm{pH}$ optimum around 4.8. This percentage increased when the illuminance was lowered $(36 \%$ at $1700 \mathrm{~lx})$. Release of $\left[{ }^{14} \mathrm{C}\right] \mathrm{mal}-$ tose continued in darkness and could be inhibited by the uncoupler carbonyl cyanide $p$-trifluoro-methoxyphenylhydrazone and by diethylstilbestrol. Net efflux of maltose was observed even at a concentration ratio of extracellular/intracellular maltose of 7.8. Exogenous $\left[{ }^{14} \mathrm{C}\right]$ maltose $(5 \mathrm{mM})$ was taken up by the cells with a rate $<2 \%$ of that of simultaneous maltose release, indicating a practically unidirectional transport. It is concluded that maltose excretion is an active-transport process.
\end{abstract}

Key words: Chlorella (symbiosis) - Maltose excretion (Chlorella, symbiosis) - Symbiosis (Chlorella-Acanthocystis) - Transport, active

\section{Introduction}

Maltose excretion has been shown to occur in the symbiotic Chlorellae from green Hydra and from the ciliates Paramecium and Stentor (see Reisser and Wiessner 1984). The influence of some physicochemical factors on this process has been investigated (Muscatine 1965; Cernichiari et al. 1969) and the origin of excreted maltose has been studied (Cernichiari et al. 1969; Zieseniss et al. 1981). Scanty data, however, exist on the possible active nature of the excretion process (Zieseniss 1982). It is the purpose of this work to present briefly the growth characteristics of a Chlorella isolated from the Heliozoan Acanthocystis and to characterize the maltose

\footnotetext{
* To whom correspondence should be addressed
}

Abbreviations: $\mathrm{DES}=$ diethylstilbestrol; $\mathrm{FCCP}=$ carbonyl cyanide p-trifluoromethoxyphenyl hydrazone; p.c. $=$ packed cells excretion by this alga, also with respect to an active transport of this sugar.

\section{Material and methods}

Plant material. Chlorella sp. strain 3.83. the endosymbiont from Acanthocistis turfacea, was obtained from Sammlung für Algenkulturen Göttingen, FRG. The alga was grown under axenic conditions in liquid medium containing the following salts in mol. $1^{-1}:\left(\mathrm{NH}_{4}\right)_{2} \mathrm{SO}_{4}, 5 \cdot 10^{-3} ; \mathrm{KH}_{2} \mathrm{PO}_{4}, 5 \cdot 10^{3} ; \mathrm{MgSO}_{4}, 10^{-3}$; $\mathrm{CaCl}_{2}, 10^{-4}$. $\mathrm{FeSO}_{4}$ and trace elements were as given by Kuhl (1962). For liquid starter cultures the growth medium was enriched with $0.5 \%$ meat extract (Merck, Darmstadt, FRG). Other conditions of growth have been described previously (Fischer et al. 1989). Maintenance cultures were kept in petri dishes on culture medium with $0.5 \%$ meat extract and $1 \%$ agar: they were stored close to a window and shaded from direct sunlight. The cells were harvested after $36 \mathrm{~d}$ at cell densities between 1.0 and $2.0 \mu \mathrm{l}$ packed cells (p.c.) $\mathrm{ml}^{-1}$ and were resuspended in $50 \mathrm{mM}$ citric acid trisodium citrate buffer $\mathrm{pH} 4.8$ at a density of $2 \mu \mathrm{l}$ p.c. $\cdot \mathrm{ml}{ }^{1}$ unless indicated otherwise.

Incubation of Chlorella with ${ }^{14} \mathrm{CO}_{2}$ : estimation of ${ }^{14} \mathrm{C}^{\prime}$ incorporation and excretion of $1^{14} \mathrm{C} /$ maltose; analysis of labeled excretion products. The procedure has been described in detail elsewhere (Fischer et al. 1989). Briefly, $1 \mu \mathrm{l}$ of packed cells suspended in $0.5 \mathrm{ml} 50 \mathrm{mM}$ citric acid - trisodium citrate buffer ( $\mathrm{pH} 4.8)$ were shaken $(260 \mathrm{rpm})$ at $28^{\circ} \mathrm{C}$ in an atmosphere containing $0.9 \%{ }^{14} \mathrm{CO}_{2}(\mathrm{v} / \mathrm{v})$ with a specific radioactivity of $7.4 \mathrm{kBq} \cdot \mu \mathrm{mol}{ }^{1}$. The illuminance was $15000 \mathrm{~lx}$ and the incubation time was $1 \mathrm{~h}$. unless indicated otherwise. Radioactivity of cells was determined by scintillation counting of a cell hydrolysate and $\left[{ }^{14} \mathrm{C}\right]$ maltose excretion by TLC of the desalted medium. making use of a TLC'-scanning device (LB 284; Berthold, Wildbad, FR(i).

Determination of extracellular maltose and of intracellular maltose. sucrose and glucose/glucose-6-phosphate. Maltose in the medium was determined after cleavage with $\alpha$-glucosidase using the hexokinase/glucose-6-phosphate dehydrogenase system (Gutmann 1974). For assays of intracellular sugars, aqueous cell extracts were obtained according to the method of Bieleski (1982) as modified by Fischer et al. (1989). The yicld of extraction was checked by adding a known amount of carrier-free $\left[{ }^{14} \mathrm{C}\right]$ maltose to the initial extraction mixture and by counting an aliquot at the end of the procedure; $83 \%$ of the radioactivity was recovered. The content of glucose + glucose-6-phosphate of the aqueous extracts was determined 
enzymatically with hexokinase/glucose-6-phosphate dehydrogenase (Bergmeyer et al. 1974). The sucrose content was obtained after incubation with invertase on the basis of the same method (Bergmeyer and Bernt 1974) and the maltose content after an additional incubation with $\alpha$-glucosidase (Gutmann 1974). The cell volume was determined as the volume inaccessible to soluble starch (Fischer et al. 1989); this polymer showed no measurable degradation or uptake by the cells within the time span of its application.

Silicone-oil centrifugation and filtration for cell sampling. For silicone-oil centrifugation, $3 \mathrm{ml}$ of $15 \%$ (w/v) trichloroacetic acid, $3 \mathrm{ml}$ silicone oil (type AR 200; Fluka, Buchs, Switzerland) and $1 \mathrm{ml}$ of $50 \mathrm{mM}$ citric acid-trisodium citrate buffer $\mathrm{pH} 4.8$ were pipetted in the given order into a siliconized centrifuge tube and precentrifuged for a short time to obtain sharp phase boundaries. The algal suspension $(250 \mu \mathrm{l}$ p.c. $)$, in $5 \mathrm{ml}$ of $50 \mathrm{mM}$ citric acid-trisodium citrate buffer $\mathrm{pH} 4.8$, was added to the top of the tube. After 5 min centrifugation at $1200 \cdot g$ the upper and middle phases were removed, the sedimented cells were resuspended in the lower phase and were kept at $4^{\circ} \mathrm{C}$ for $30 \mathrm{~min}$. After another centrifugation the supernatant (=cell extract) was taken and repeatedly extracted with diethyl ether to remove trichloroacetic acid. After concentration to an appropriate volume and adjustment of $\mathrm{pH}$, maltose was determined as described above. In a parallel experiment, the same amount of cells was vaccum-filtered on a cellulose-nitrate membrane filter $(0.45 \mu \mathrm{m})$ and washed three times with ice-cold $50 \mathrm{mM}$ citric acid-trisodium citrate buffer $\mathrm{pH} 4.8$. The filter with the cells was extracted for $30 \mathrm{~min}$ at $4^{\circ} \mathrm{C}$ in $3 \mathrm{ml}$ of $15 \%(\mathrm{w} / \mathrm{v})$ trichloracetic acid; the following procedures were as above.

\section{Results}

Morphology and growth characteristics of Chlorella $s p$. 3.83. The cells contained a cup-like chloroplast and were egg-shaped or almost spherical in young and mature stages, respectively; the diameter of mature cells was approx. $7.5 \mu \mathrm{m}$. Normally, four autospores were released

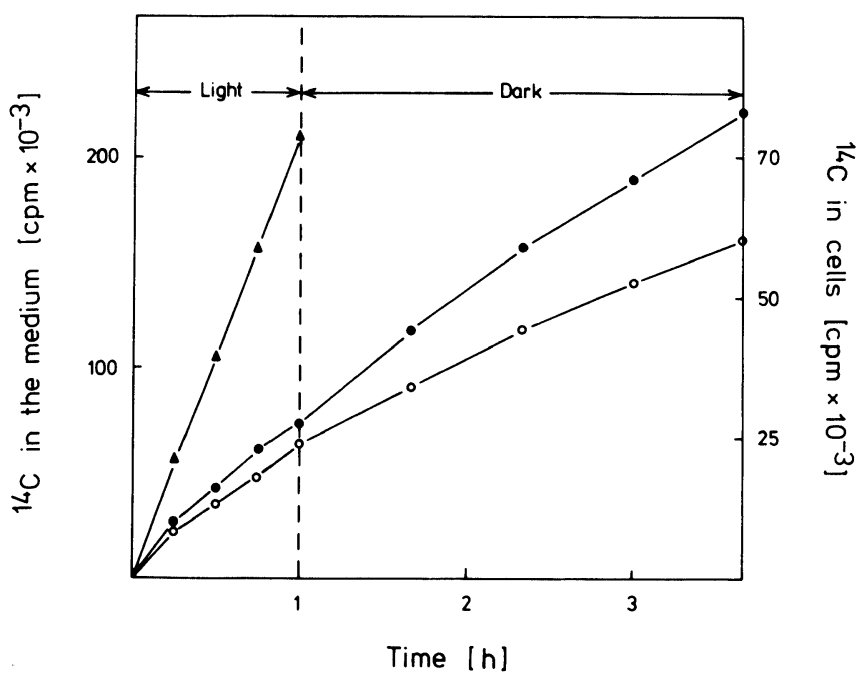

Fig. 1. Kinetics of ${ }^{14} \mathrm{C}$-labeling of cells and of excretion products of symbiotic Chlorella sp. 3.83. $\mathbf{\Lambda}-\mathbf{\Delta}$, radioactivity in cells; $\bullet$, radioactivity in the medium; $\mathrm{O}-\mathrm{O}$, radioactivity of uncharged material in the medium. The rate of ${ }^{14} \mathrm{CO}_{2}$ fixation was $541 \mu \mathrm{mol}$. $\mathrm{h}^{-1} \cdot(\mathrm{ml} \text { p.c. })^{-1}$. After the light period, one sample was centrifuged, the cells were resuspended in fresh buffer, transferred into a darkened vial with air as gas phase and were shaken. Every half hour the medium was removed for counting and was replaced by fresh buffer; the cumulated counts were plotted in the graph

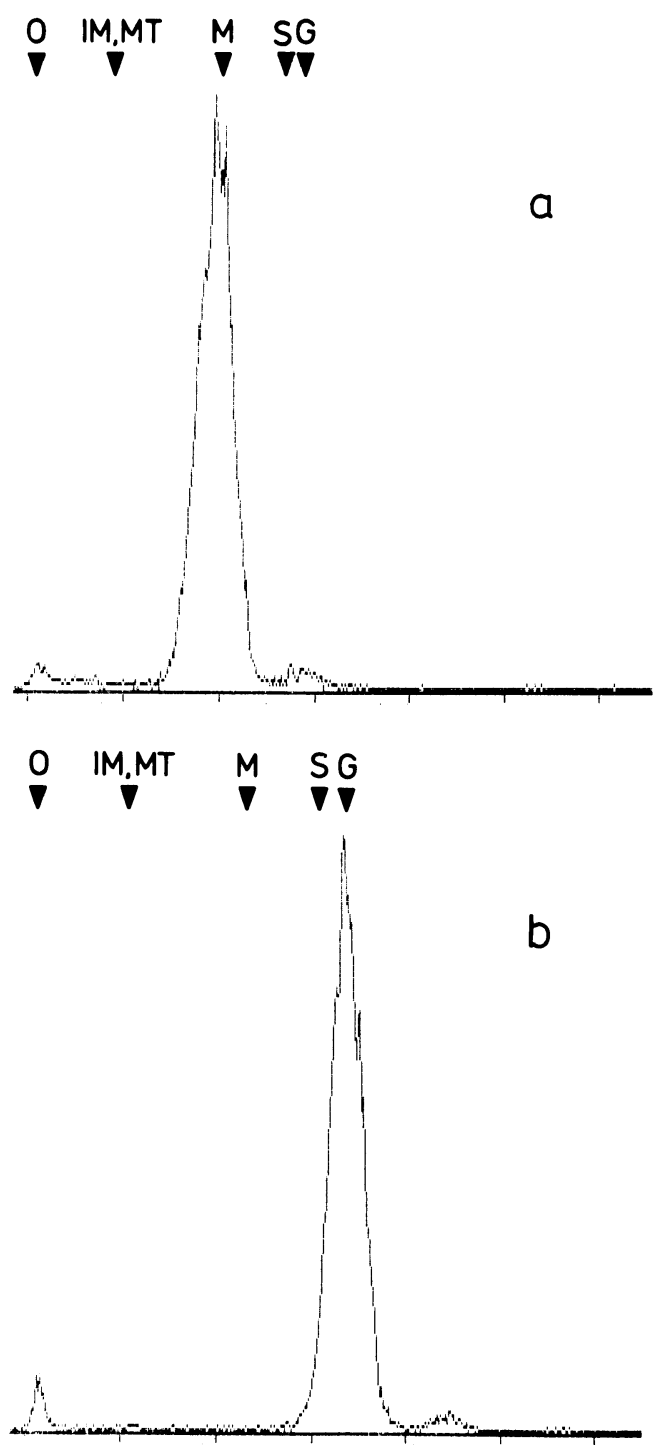

Fig. 2a, b. Scans for radioactivity of thin-layer chromatograms. a Excretion products of Chlorella sp. 3.83 at $\mathrm{pH} 4.8$; the medium was treated with mixed ion-exchange resins before separation (Fischer et al. 1989). b Analysis of the peak at the position of maltose in a. The peak material was eluted and incubated for $2 \mathrm{~h}$ at $37^{\circ} \mathrm{C}$ in a total volume of $0.5 \mathrm{ml} 50 \mathrm{mM}$ Na-citrate buffer pH 4.8 containing $7 \mathrm{U}$ amyloglucosidase (Boehringer, Mannheim, FRG), treated with a mixed-bed ion exchanger (MB-3; Serva, Heidelberg, FRG) and was rechromatographed. In a and $\mathbf{b}$, silica-gelcoated aluminum sheets were used with acetone: $n$-butanol: $\mathrm{H}_{2} \mathrm{O}=$ 70:15:15 (by vol.) as solvent system. The positions of reference substances are indicated: $G=$ glucose, $S=$ sucrose, $M=$ maltose, $M T=$ maltotriose $; I M=$ isomaltose $O=$ origin

from mother cells. Growth was exponential up to a cell density of approx. $7.7 \cdot 10^{7}$ cells $\cdot \mathrm{ml}^{-1}$ with a doubling time of $14 \mathrm{~h}$. The addition of the combined vitamins $B_{1}\left(1 \mathrm{mg} \cdot \mathrm{ml}^{-1}\right)$ and $B_{12}\left(0.1 \mathrm{mg} \cdot \mathrm{l}^{-1}\right)$, which is essential for other symbiotic Chlorellae (Reißer 1975; Zieseniß et al. 1981; Mücke 1985), did not influence the growth rate of Chlorella sp. 3.83.

Fixation of ${ }^{14} \mathrm{CO}_{2}$; excretion and analysis of labeled products. Assimilation of ${ }^{14} \mathrm{CO}_{2}$ was linear for at least 
$1 \mathrm{~h}$ and was accompanied by excretion of radioactive material (Fig. 1). This amounted to between 10 and 20\% of total fixed ${ }^{14} \mathrm{C}$ in several experiments. Upon darkening, excretion continued with little change in rate and, after $2 \mathrm{~h}$ in darkness, had reached a value of $>30 \%$. After treatment with mixed-bed ion exchangers, most of the labeled excretion products (typically $80 \%$ of them) were still in solution and, therefore, are considered to represent uncharged compounds. Thin-layer chromatography of these showed a conspicous peak at the position of maltose (Fig. 2a). After elution, treatment with amyloglucosidase and rechromatography the position of radioactivity had changed to that of glucose (Fig. 2b). Thus, maltose is obviously the main excretion product of the Acanthocystis endosymbiont.

Parameters influencing maltose excretion. The dependence of maltose excretion and ${ }^{14} \mathrm{CO}_{2}$ fixation on the $\mathrm{pH}$ of the medium is shown in Fig. 3. Maximum rates of maltose excretion occurred in the acidic range between $\mathrm{pH} 4.5$ and $\mathrm{pH} 4.8$. Quite low rates were observed at $\mathrm{pH}$ values $>5.4 ;{ }^{14} \mathrm{CO}_{2}$ fixation, however, extended at reasonable rates up to $\mathrm{pH}$ 7.6. At the higher $\mathrm{pH}$ values, maltose was still the dominating compound in the small amount of excreted material.

Maltose excretion was proportional to illuminance, up to about $3000 \mathrm{~lx}$, whereas ${ }^{14} \mathrm{CO}_{2}$ fixation in the cells continued in a linear fashion up to $6000 \mathrm{~lx}$ (Fig. 4). The percentage of ${ }^{14} \mathrm{C}$ excreted as maltose, therefore, was higher at the lower illuminances; at $1700 \mathrm{~lx}$ it amounted to $36 \%$ of the total fixed ${ }^{14} \mathrm{C}$. The temperature optimum for $\left[{ }^{14} \mathrm{C}\right]$ maltose excretion in the light and for ${ }^{14} \mathrm{CO}_{2}$ assimilation was broad, extending between $28^{\circ} \mathrm{C}$ and $36^{\circ} \mathrm{C}$ (data not shown).

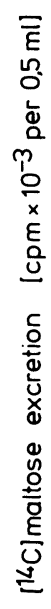

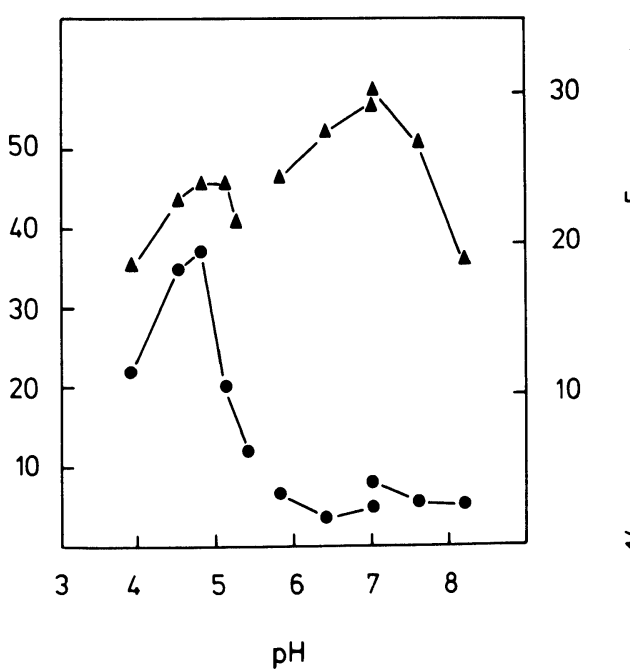

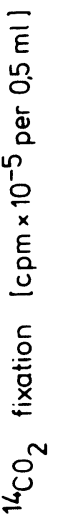

Fig. 3. Dependence on $\mathrm{pH}$ of ${ }^{14} \mathrm{CO}_{2}$ fixation by cells of Chlorella sp. 3.83 and of $\left[{ }^{14} \mathrm{C}\right]$ maltose excretion. $-\bullet$, maltose excretion; $\Delta,{ }^{4} \mathrm{CO}_{2}$ fixation. The following buffers were used at a concentration of $50 \mathrm{mM}$ throughout: citric acid-trisodium citrate (pH 3.9-5.4), 2-(N-morpholino)ethanesulfonic acid- $\mathrm{NaOH}$ (pH 5.8-7.0), 4-(2-hydroxyethyl)-1-piperazineethanesulfonic acid$\mathrm{NaOH}(\mathrm{pH} 7.0-8.2)$. The rate of maltose excretion at $\mathrm{pH} 4.8$ was $7.8 \mu \mathrm{mol} \cdot \mathrm{h}^{-1} \cdot(\mathrm{ml} \text { p.c. })^{-1}$

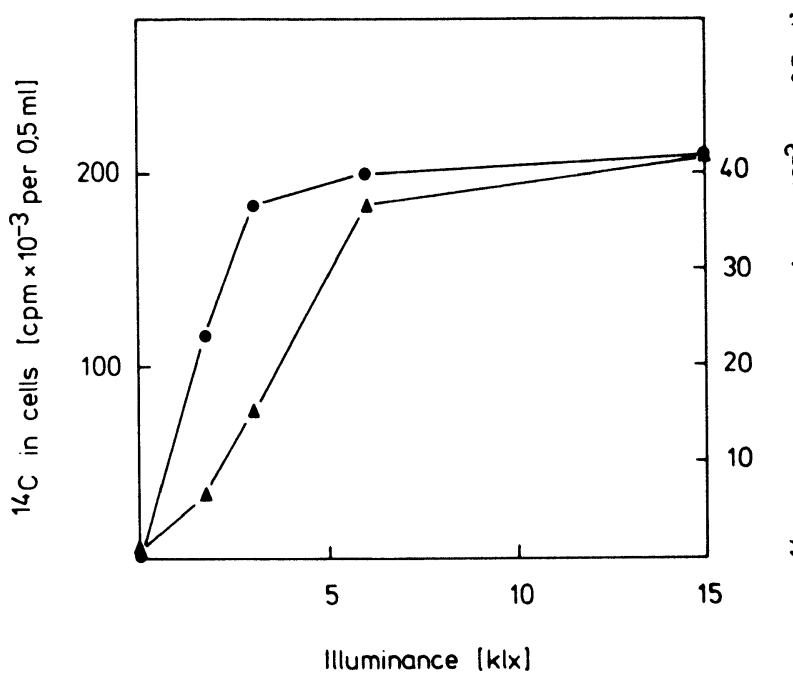

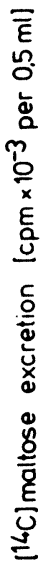

Fig. 4. Fixation of ${ }^{14} \mathrm{CO}_{2}$ and excretion of $\left[{ }^{1+} \mathrm{C}\right]$ maltose by cells of Chlorella sp. 3.83 in the light as a function of illuminance. $\triangle \Delta .{ }^{14} \mathrm{C}$ in cells; $\bullet$. excreted $\left[{ }^{14} \mathrm{C}\right]$ maltose. Different illuminances were achieved by calibrated wire screens mounted in front of the vessels, other conditions as given in Material and methods

Table 1. The effect of FCCP and of DES on $\left[{ }^{1+} \mathrm{C}\right]$ maltose excretion by cells of (hlorella sp. 3.83 in the dark. After $1 \mathrm{~h}$ of ${ }^{14} \mathrm{CO}_{2}$ assimilation (see Material and methods) the eells were centrifuged. resuspended in fresh buffer and poison was added in ethanolic solution. to the control only ethanol. After shaking for $1 \mathrm{~h}$ in the dark in air $\left[{ }^{14} \mathrm{C}\right]$ maltose in the medium was determined. The rates of maltose excretion are based on the specific radioactivity of the ${ }^{14} \mathrm{CO}_{2}$

\begin{tabular}{|c|c|c|}
\hline Poison & $\begin{array}{l}\text { Concentration } \\
\text { (M) }\end{array}$ & $\begin{array}{l}{\left[{ }^{14} \mathrm{C}\right] \mathrm{maltose} \text { excretion }} \\
\left.\left(\mu \mathrm{mol} \cdot \mathrm{h}^{-1} \cdot(\mathrm{ml} \mathrm{p.c.})\right)^{-1}\right)\end{array}$ \\
\hline FCCP & $\begin{array}{cc}0 \\
10 & 5 \\
10 & +\end{array}$ & $\begin{array}{l}4.42 \\
1.11 \\
0.84\end{array}$ \\
\hline DES & $\begin{array}{l}0 \\
10^{-5} \\
5 \cdot 10^{-5} \\
10^{-4}\end{array}$ & $\begin{array}{l}4.63 \\
2.92 \\
0.93 \\
0.74\end{array}$ \\
\hline
\end{tabular}

Evidence for active transport of maltose. Sensitivity of maltose excretion against the uncoupler carbonyl cyanide $p$-trifluoromethoxy phenyl hydrazone (FCCP) and the inhibitor diethylstilbestrol (DES) would be expected for an active export step. Diethylstilbestrol has been reported to inhibit oxidative phosphorylation and to act on plant plasmalemma ATPase (Balke and Hodges 1977). After assimilation of ${ }^{14} \mathrm{CO}_{2}$ in the light, the export of $\left[{ }^{14} \mathrm{C}\right]$ maltose was found to be inhibited by FCCP and by DES (Table 1). These results are consistent with a mechanism depending on intact $\mathrm{pH}$ gradients and-or the presence of ATP. The data could be explained. however, also if energy-requiring steps were involved in the formation of maltose.

Evidence for active transport was derived from measurements of maltose excretion against a concentration gradient. For this purpose an algal suspension was made $2 \mathrm{mM}$ with respect to maltose at the beginning of an 
Table 2. Time course of changes in intra- and extracellular sugar concentrations in a cell suspension of Chlorella $\mathrm{sp}$. 3.83. Cells were suspended at a cell density of $100 \mu \mathrm{l}$ p.c. $\cdot \mathrm{ml}^{-1}$ in $50 \mathrm{ml} 50 \mathrm{mM}$ citric acid-trisodium citrate buffer ( $\mathrm{pH} 4.8)$ containing $2 \mathrm{mM}$ maltose, and were shaken in a 500-ml Erlenmeyer flask which was continuously gassed with $2 \%(\mathrm{v} / \mathrm{v}) \mathrm{CO}_{2}$ in air. Illumination was $15000 \mathrm{~lx}$ and the temperature $28^{\circ} \mathrm{C}$. After different times, $6.5-\mathrm{ml}$ aliquots of the suspension were withdrawn, vacuum-filtered on $0.45-\mu \mathrm{m}$ cellulose-nitrate membrane filters $(5 \mathrm{~cm}$ diameter $)$ and washed three times with ice-cold citrate buffer. Extracellular maltose was assayed enzymatically in aliquots from the filtrate and intracellular maltose, sucrose and glucose + glucose-6-phosphate in and methods). Intracellular concentrations are corrected for intercellular water content of packed cells

\begin{tabular}{llllllll}
\hline $\begin{array}{l}\text { Concentration } \\
(\mathrm{mM})\end{array}$ & \multicolumn{9}{l}{ Time (min) } \\
\cline { 2 - 7 } & 0 & 30 & 60 & 90 & 120 & 150 & 180 \\
\hline
\end{tabular}

Intracellular sugar

Glucose + glucose-6-phosphate -

Sucrose

$\begin{array}{llllll}0.34 & 0.34 & 0.32 & 0.31 & 0.29 & 0.40\end{array}$

Maltose

$\begin{array}{llllll}4.38 & 3.93 & 3.98 & 3.96 & 3.86 & 4.79\end{array}$

Extracellular maltose

$\begin{array}{llllll}0.43 & 0.38 & 0.35 & 0.45 & 0.51 & 0.59\end{array}$

Maltose concentration ratio

2.172 .382 .743 .203 .503 .944 .57

$-\quad 5.5 \quad 7.2 \quad 9.2 \quad 7.8 \quad 7.7 \quad 7.8$ algal extracts obtained according to Bieleski (1982; see Material

outside/inside

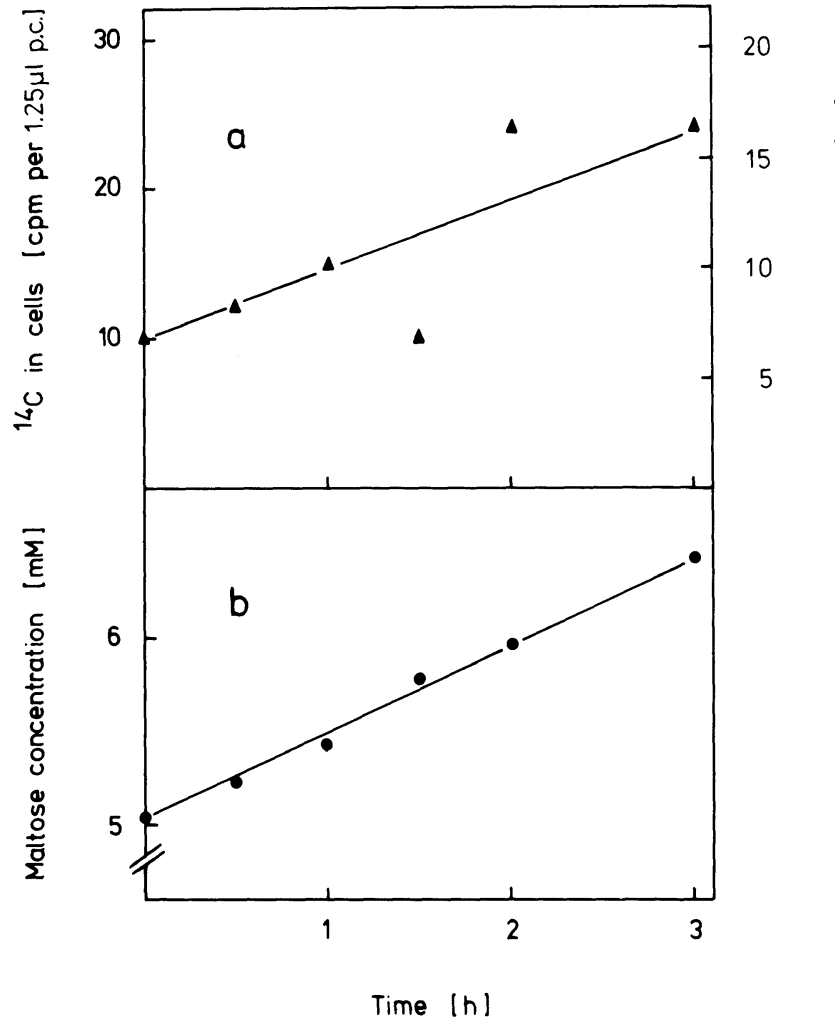

experiment and the maltose concentration in the medium was followed for a period of $3 \mathrm{~h}$; during that time, samples of cells were collected by filtration, extracted and the cellular maltose concentration was determined. Table 2 shows that the intracellular concentration increased only from $0.43 \mathrm{mM}$ to $0.59 \mathrm{mM}$, whereas the extracellular maltose concentration rose from $2.2 \mathrm{mM}$ to $4.57 \mathrm{mM}$. Thus, net maltose transport occurred against a concentration gradient, indicating an active transport. The reason for the relatively constant concentration ratios outside/inside of 7-8 after different times (Table 2) is the more or less parallel increase of intracellular and extracellular maltose concentration. The data, however, do not indicate an equilibrium between efflux and influx: note that all through the experiment a net efflux took place at a fairly constant rate. Even when the medium was made $5 \mathrm{mM}$ with respect to maltose, net excretion of this sugar was observed (Fig. $5 \mathrm{~b}$ ). To be sure that the cells had not lost large amounts of maltose by the filtration and washing procedure leading to values of intracellular maltose concentration that were too low, a control experiment was carried out employing the silicone-oil centrifugation technique for cell separation (see Werkheiser and Bartley 1957; Material and methods). With both methods, essentially the same intracellular maltose concentration was obtained, e.g. $0.41 \mathrm{mM}$ (silicone-oil centrifugation) and $0.48 \mathrm{mM}$ (filtration).

The intracellular concentration of glucose + glucose6-phosphate was found to be comparable to that of maltose, whereas sucrose was present at a 10 -times higher concentration ( $4.2 \mathrm{mM}$; Table 2). Since, however, no sucrose was encountered in the medium (Fig. 2a), the maltose-export system seems to be quite specific (see Zieseniß 1982).
Fig. 5a, b. Kinetics of $\left[{ }^{14} \mathrm{C}\right]$ maltose uptake (a) and of maltose excretion (b) by Chlorella sp. 3.83. a For uptake measurements, $4.5 \mathrm{ml}$ of algal suspension $\left(50 \mu \mathrm{l}\right.$ p.c. $\cdot \mathrm{ml}^{-1}$ in $50 \mathrm{mM}$ citric acid-trisodium citrate buffer, $\mathrm{pH} 4.8$ ) were shaken in the dark in a $25-\mathrm{ml}$ Erlenmeyer flask in the presence of $\left[{ }^{14} \mathrm{C}\right]$ maltose $(5 \mathrm{mM})$ with a specific radioactivity of $658 \mathrm{~Bq} \cdot \mu \mathrm{mol}^{-1}$ equivalent to $34640 \mathrm{cpm} \cdot \mu \mathrm{mol}^{-1}$. At different times, $0.5 \mathrm{ml}$-samples were subjected to vacuum filtrations, washed three times with $2 \mathrm{ml}$ ice-cold suspension buffer and the cells' radioactivity was determined (Fischer et al. 1989). At $15 \mathrm{~min}$ and $180 \mathrm{~min}$, an aliquot of unfiltered suspension was taken for determination of total radioactivity. For calculation of isotopic equilibration the values of packed cells were corrected for $34 \%$ intercellular water. b Excreted maltose was determined enzymatically (see Material and methods) after the cells had been removed by centrifugation; incubation conditions were as in a except that unlabeled maltose was used

If maltose leaves the cell by catalyzed diffusion, one should expect an uptake of external $\left[{ }^{14} \mathrm{C}\right]$ maltose. When Chlorella was incubated in the presence of labeled maltose, less than $20 \%$ of isotopic equilibrium was reached in the cells after $3 \mathrm{~h}$ and the rate of uptake was only $0.11 \mu \mathrm{mol} \cdot \mathrm{h}^{-1} \cdot(\mathrm{ml} \text { p.c. })^{-1}$ as calculated from the specific radioactivity of the $\left[{ }^{14} \mathrm{C}\right]$ maltose (Fig. 5a). At the same time, maltose was excreted at a more than 80 -fold rate $\left(9.2 \mu \mathrm{mol} \cdot \mathrm{h}^{-1} \cdot(\mathrm{ml} \text { p.c. })^{-1}\right.$, Fig. $\left.5 \mathrm{~b}\right)$. Thus, the alga seems to drive a unidirectional maltose transport and is almost inaccessible to this sugar from the outside. These flux characteristics are generally associated with active transport (Komor 1982).

Glucose was taken up by Chlorella sp. 3.83 at reasonable rates $\left(7.3 \mu \mathrm{mol} \cdot \mathrm{h}^{-1} \cdot(\mathrm{ml} \text { p.c. })^{-1}\right.$ at $\mathrm{pH} 4.8$, $29 \mu \mathrm{mol} \cdot \mathrm{h}^{-1} \cdot(\mathrm{ml} \text { p.c. })^{-1}$ at $\mathrm{pH} 6.5$; data not shown), whereas sucrose uptake was almost nil. 


\section{Discussion}

The symbiont from the protozoan Acanthocystis is able to excrete substantial amounts of maltose, a property which is also exhibited by Chlorellae endosymbiotic with Hydra (Muscatine 1965; Cernichiari 1969), Paramecium (Muscatine et al. 1967; Zieseniss et al. 1982; Mücke 1985) and Stentor (Reisser 1981). The observed rates of maltose excretion $\left(4.0-9.2 \mu \mathrm{mol} \cdot \mathrm{h}^{-1} \cdot(\mathrm{ml} \mathrm{p.c.})^{-1}\right)$ are of the same order as the value given by Cernichiari et al. $\left(1.8 \mu \mathrm{mol} \cdot \mathrm{h}^{-1} \cdot(\mathrm{ml} \mathrm{p.c.})^{-1} ; 1969\right)$. The $\mathrm{pH}$ dependence of maltose release with an optimum in the acidic range (Fig. 3) has also been reported for the symbionts of $\mathrm{Hyd}$ ra (Muscatine 1965; Cernichiari et al. 1969) and Paramecium (Zieseniss 1982; Mücke 1985). Glucose excretion from Chlorella sp. 211-40c, a freshwater sponge symbiont, displays a similar pH profile (Fischer et al. 1989), which is also indicated for maltose and trehalose release from Chlorella strains isolated from Stentor (Reisser 1981) and Paramecium (Pardy et al. 1989), respectively. This widely distributed characteristic strongly indicates a common mechanism of sugar export in these symbiotic Chlorellae.

Cytological features of Chlorella sp. 3.83 (cell size, number of autospores; shape of chloroplast) are well comparable to those of other maltose-excreting algae (Cernichiari et al. 1969; Reisser 1984). Besides all the physiological and cytological similarities there are differences in this group of Chlorellae, e.g. in Chlorella sp. 3.83 photosynthesis and maltose excretion were different in their light-saturation characteristics (Fig. 4) whereas they agreed in the symbiont from Hydra (Cernichiari et al. 1969). A nutritional difference is indicated by the ability of strain 3.83 to grow without added vitamins, whereas isolates from Paramecium require addition of vitamins $B_{1}$ and $B_{12}$ (Reisser 1975; Zieseniss et al. 1981; Mücke 1985).

The sensitivity of maltose excretion to FCCP and DES points to an energy-requiring step in the transport and-or in the biosynthesis of maltose. The former possibility seems to be realized in a Paramecium symbiont whose maltose excretion was inhibited by vanadate and by DES with little effect on cellular ATP content and respiration; therefore, these compounds were assumed to act on an energy-transforming plasmalemma ATPase involved in maltose export (Zieseniss 1982). Net excretion of maltose occurred even when this sugar was sevento eightfold more concentrated in the medium than within the cell (Table 2). This finding indicates an activetransport process (see Komor 1982). If, however, the cytoplasm from which maltose has to be excreted, comprises less than $1 / 7.5 \hat{=13 \%}$ of the cell volume (and if all intracellular maltose is located there), a passive efflux depending on, e.g. catalyzed diffusion would be conceivable. The volume of the cytoplasm is not known for Chlorella sp. 3.83 ; a value of $40 \%$ can be derived for Chlorella vacuolata from a study employing quantitative stereology and three-dimensional reconstruction (Atkinson et al. 1974).

The practically unidirectional movement of maltose into a medium containing $5 \mathrm{mM}$ maltose (ratio of efflux/ influx $>80$.. see Fig. 5) would require cytosolic concentrations of maltose much higher than $5 \mathrm{mM}$ if a passive transport were involved; a value of at least $5 \cdot 80=$ $400 \mathrm{mM}$ has to be postulated for the case of unmediated diffusion. A more favored explanation for the predominant maltose efflux is the action of a vectorial activetransport system (see Komor 1982).

For Escherichica coli, active uptake of maltose is known in reasonable detail (Wiesmeyer and Cohn 1960: Szmelcman and Schwartz 1976: Shuman and Treptow 1985). To obtain a closer insight into the mechanism of maltose transport in the symbiotic Chlorellac further experimentation is needed, eventually employing isolated plasmalemma vesicles.

This work was supported by the Deutsche Forschungsgemeinschaft. Thanks are due to Doris Meindl for skillful experimental help.

\section{References}

Atkinson, A.W., Jr., John, P.C.L.. Gunning, B.L.S. (1974) The growth and division of the single mitochondrion and other organelles during the cell cycle of Chlorella, studied by quantitative stereology and three dimensional reconstruction. Protoplasma 81, 77109

Balke, N.E.. Hodges, T.K. (1977) Inhibition of ion absorption in oat roots: comparison of diethylstilbestrol and oligomycin. Plant Sci. Lett. 10, $319 \quad 325$

Bergmeyer, HI.U., Bernt, E. (1974) Saccharose. In: Methoden der enzymatischen Analyse, vol. II. pp. 1221 1224, Bergmeyer. H.U., ed. Verlag Chemie, Weinheim

Bergmeyer, H.U., Bernt. E.. Schmidt, I., Stork. H. (1974) 1)-(ilucose: Bestimmung mit Hexokinase and (Blucose-6-phosphatDehydrogenase. In: Methoden der enzymatischen Analyse, vol. II, pp. 1241 1246, Bergmeyer, H.U.. ed. Verlag (hemie. Weinheim

Bieleski, R.L. (1982) Sugar alcohols. In: Encyclopedia of plant physiology. N.S., vol. 13A: Plant carbohydrates I. pp. 158192. Loewus. F.A.. Tanner, W., eds. Springer, Berlin Heidelberg New York

Cernichiari, E.. Muscatine L.. Smith. D).C. (1969) Maltose excretion by the symbiotic algae of $H_{y}$ dra ciridis. Proc. R. Soc. London Ser. B 173, 557 576

Fischer, A., Meindl, D., Loos, E. (1989) (jlucose excretion by the symbiotic Chlorella of Spongilla flutiatilis. Planta 179, 251 256

Gutmann. J. (1974) Maltose. In: Methoden der enzymatischen Analyse, vol. II. pp. 1230) 1233, Bergmeyer, H.U.. ed. Verlag Chemic, Weinheim

Komor, E. (1982) Transport of sugar. In: Encyclopedia of Plant Physiology, N.S., vol. 13A: Plant carbohydrates I. pp. 635676. Loewus, F.A., Tanner, W., eds. Springer. Berlin Heidelberg New York

Kuhl, A. (1962) Zur Physiologie der Speicherung kondensierter anorganischer Phosphate in (hlorella. In: Beiträge zur Physiologie und Morphologie der Algen, pp. 157 166. Deutsche Botanische Gesellschaft, ed. Fischer, Stuttgart

Mücke. J. (1985) Basisversuche zur Ethanolproduktion aus Kohlendioxid und Licht. Dissertation. Aachen

Muscatine, L. (1965) Symbiosis of hydra and algac. III. Extracellular products of the algac. Comp. Biochem. Physiol. 16, 7792

Muscatine, L.. Karakashian, S.J., Karakashian. M.W. (1967) Soluble intracellular products of algae symbiontic with a ciliate. a sponge and a mutant hydra. Comp. Biochem. Physiol. 20. $1-12$

Pardy, R.L., Spargo, B., Crowe, J.H. (1989) Release of trehalose by symbiotic algac. Symbiosis 7, 149 158 
Reisser, W. (1975) Zur Taxonomie einer auxotrophen Chlorella aus Paramecium bursaria. Planta 153, 481-485

Reisser, W. (1981) The endosymbiotic unit of Stentor polymorphus and Chlorella sp. Morphological and physiological studies: Protoplasma 105, 273-284

Reissr, W. (1984) The taxonomy of green algae endosymbiotic in ciliates and a sponge. Br. Phycol. J. 19, 309-318

Reisser, W., Wiessner, W. (1984) Autotrophic eukaryotic freshwater symbionts. In: Encyclopedia of plant physiology, N.S., vol. 17: Cellular interactions, pp. 59-74, Linskens, H.F., Heslop Harrison, J., eds. Springer, Berlin Heidelberg New York

Shuman, H.A., Treptow, N.A. (1985) The maltose-maltodextrin transport system of Escherichia coli K-12. In: The Enzymes of biological membranes, 2nd edn., vol. 3, pp. 561-575, Martonosi, A.N., ed. Plenum Press, New York London

Szmelcman, S., Schwartz, M. (1976) Maltose transport in Escherichia coli $\mathrm{K} 12$, a comparison of transport kinetics in wildtype and $\lambda$-resistent mutants with the dissociation constants of the maltose-binding protein as measured by fluorescence quenching. Eur. J. Biochem. 65, 13-19

Werkheiser, W., Bartley, W. (1957) The study of steady-state concentrations of internal solutes of mitochondria by rapid centrifuged transfer to a fixation medium. Biochem. J. 66, 79-91

Wiesmeyer, H., Cohn, M. (1960) The characterization of the pathway of maltose utilization by Escherichia coli III. A description of the concentration mechanism. Biochim. Biophys. Acta 39 440-447

Zieseniss, E. (1982) Symbiose-spezifische Synthese und Exkretion von Maltose durch Chlorella spec. aus Paramecium bursaria. Dissertation, University of Göttingen, FRG

Zieseniss, E., Reisser, W., Wiessner, W. (1981) Evidence of de novo synthesis of maltose excreted by the endosymbiotic Chlorella from Paramecium bursaria. Planta 153, 481-485

Received 15 December 1989; accepted 23 February 1990 